\title{
Meiotic effects of Robertsonian translocations in tuco-tucos of the Ctenomys perrensi superspecies (Rodentia: Ctenomyidae)
}

\author{
Lanzone $^{* 1,2}$ Cecilia, Mabel D. Giménez ${ }^{1,3}$, Juan L. Santos $^{4}$ and Claudio J. Bidau 5 \\ ${ }^{1}$ Laboratorio de Genética Evolutiva, Universidad Nacional de Misiones, (3300) Posadas, Misiones, Argentina. \\ ${ }^{2}$ Grupo de Investigaciones de la Biodiversidad, Instituto Argentino de Investigaciones en Zonas Áridas, CRICYT, \\ CONICET, Parque Gral. San Martín, Av. Ruiz Leal s/n, CC 507, (5500) Mendoza, Argentina. Tel. (0261)- \\ 44280080. \\ ${ }^{3}$ Department of Biology, University of York, PO Box 373, York YO10 5YW, UK. \\ ${ }^{4}$ Departamento de Genética, Facultad de Biología, Universidad Complutense de Madrid, (28040) Madrid, Spain. \\ ${ }^{5}$ Laboratório de Biologia e Parasitologia de mamíferos Silvestres Reservatórios, Departamento de Medicína Tropi- \\ cal, Instituto Oswaldo Cruz, (21046-900) Rio de Janeiro, Brazil.
}

\begin{abstract}
Meiotic behaviour was studied in males of the Ctenomys perrensi superspecies from Argentina that show variations in their chromosome number mostly due to Robertsonian translocations ( $\mathrm{Rb})$. A significant positive correlation between cell chiasma frequencies and total chromosome numbers was found. The reduction in chiasma frequency observed in individuals with $\mathrm{Rb}$ rearrangements occurred mainly at expenses of proximal and interstitial chiasmata, although significant differences between $\mathrm{Rb}$ trivalents and bivalents both in chiasma distribution and univalent frequency were also observed. Nevertheless, not all changes in chiasma distributions could be ascribed to Rb rearrangements. Chromosome synapsis was analysed in Rb hetero- and homozygotes. Trivalents showed a high frequency of synapsis at pericentromeric regions, suggesting no mechanical incompatibilities or delay in the synaptonemal complex formation in such regions. The relationship between chiasma distributions and synaptic patterns is discussed and a hypothesis about the possible role of telocentric or subtelocentric regions in these processes is proposed. It is also concluded that one or two Rb translocations in heterozygosis have weak direct effects on the fertility of the male carriers; therefore $C$. perrensi superspecies may be prone to maintain $\mathrm{Rb}$ chromosomal rearrangements.
\end{abstract}

Key words: chiasma frequency, chiasma localisation, chromosomal rearrangements, Ctenomys, synaptonemal complex.

\section{INTRODUCTION}

Robertsonian $(\mathrm{Rb})$ translocations are common as chromosome polymorphisms or fixed differences between populations (BAKER et al. 1985; BIDAU 1990; HATFIELD et al. 1992; NACHMAN 1992a; SeArle 1993; SeArle et al. 1993; Rogatcheva et al. 1997; 1998; Bidau and Martí 2002; Piálek et al. 2005). In Rb heterozygous meiosis, the biarmed chromosome and its acrocentric homologues must pair, form chiasmata, orientate and segregate disjunctionally which is that expected in balanced polymorphisms, but not when $\mathrm{Rb}$ rearrangements act as isolating mechanisms (White 1978; Hewitt 1979; John 1983; King 1993; RiESEBERg 2001). Secondary contact between

\footnotetext{
* Corresponding author: e-mail: celanzone@lab.cricyt.edu.ar
}

populations differing for $\mathrm{Rb}$ translocations produces hybrid zones where hybrids may show decreased fertility relative to the parental forms. Synaptic failure, association of unsynapsed autosomal segments with asynaptic regions of sex chromosomes, and other factors affecting early presynaptic stages have been related to decreases of fertility in Rb heterozygotes (KING 1993). Furthermore, $\mathrm{Rb}$ rearrangements usually modify chiasma frequency and distribution patterns, which may disrupt groups of coadapted genes (BIDAU et al. 2001).

Fossorial Ctenomys rodents (tuco-tucos) are endemic to South America, and represent the most chromosomally variable mammal genus. Ctenomys includes 67 named species (BIDAU 2006, and personal observations), and chromosome numbers range from $2 \mathrm{n}=10$ in C. steinbachi to $2 \mathrm{n}=70$ in C. dorbignyi and C. pearsoni (КІвLISKY et al. 1977; ANDERSON et al. 1987; ORTELls 
et al. 1990; ArgüELLES et al. 2001). Karyotypes of Ctenomys species are diverse, owing to a wide range of rearrangements (OrTELls et al. 1990; Ortells 1995; Braggio et al. 2000; Giménez et al. 1997; 1999; 2002; ArgüELLEs et al. 2001; BIDAU 2006). However, meiotic effects of chromosomal rearrangements are poorly understood in this genus (LANZONE et al. 2002).

A group of closely related Ctenomys populations, inhabiting Corrientes province (Argentina), the C. perrensi superspecies (ORTELls 1995; GiMÉNEZ et al. 2002; LANZONE et al. 2002), shows a heterogeneous chromosomal constitution. Diploid numbers range from 40 to 70 mainly due to a system of $\mathrm{Rb}$ translocations (ORTELLS et al. 1990; GIMÉNEZ et al. 2002). Since this superspecies is of recent evolutionary origin (GIMÉNEZ et al. 2002), it is feasible that hybridisation between chromosomally distinct populations could produce hybrids with reduced fertility due to meiotic disturbances. If the chromosomal rearrangements are of recent origin, compensatory mechanisms for the restoration of fertility, and the maintenance of polymorphysm, might have not yet arisen. However, comparison of molecular and chromosomal data has shown that relatively neutral variants of $\mathrm{Rb}$ chromosomes are formed and maintained more frequently in some taxa than in others (Searle 1993; Nachman and Searle 1995; CoLANGelo et al. 2005). Previous results in Ctenomys, indicate that the sex chromosome pair displays a pattern of axis differentiation during pachytene that leads to full synapsis of both $\mathrm{X}$ and $\mathrm{Y}$ chromosomes (LAnzone et al. 2002). This behaviour might prevent possible interactions with unsynapsed regions of $\mathrm{Rb}$ trivalents that could lead to infertility (KIng 1993; TURNER et al. 2005).

In this paper, we analyse chiasma frequencies, chiasma distributions and synaptic patterns of $\mathrm{Rb}$ hetero- and homozygotes males of the $C$. perrensi superspecies to assess the effects of chromosomal repatterning in this group of tuco-tucos.

\section{MATERIALS AND METHODS}

Trapping locality and the number of specimens of Ctenomys perrensi superspecies (" $\mathrm{C}$. perrens $\left.i^{\prime \prime}\right)$ analysed in this study are indicated in Table 1 and Fig. 1. In addition, specimens of different species, namely: C. roigi and C. dorbignyi that belong to the same species complex (GIMÉNEz et al. 2002), C. opimus, a species with low chromosome number from a different lineage, and an Octodontid (the sister familiy of the Ctenomyidae) with $2 \mathrm{n}=102$, Tympanoctomys barrerae, that were not heterozygous for $\mathrm{Rb}$ translocations were used as controls (Table 1). Karyotypying followed a bone marrow short-term culture protocol (Giménez et al. 1999). Meiotic preparations were made according to Evans et al. (1964). C-banding was used to detect centromere location and chiasma positioning. The procedure used was that of EIBERG (1974): slides were aged at room temperature 7 - 10 days, incubated in Earle's solution, $\mathrm{pH}=8.5-9.0$ at $85^{\circ} \mathrm{C}$ for $30 \mathrm{~min}$, washed with distilled water, air-dried, and stained with $4 \%$ buffered Giemsa. Chiasmata were recorded at diakinesis as: proximal (P), interstitial (I) and distal (D) relative to the centromere (BIDAU et al. 2001). Means, standard deviations and coefficients of variation $\left([\mathrm{sd} / \mathrm{mean}]^{*} 100\right)$ were calculated. Normality of data was estimated through the Kolmogorov-Smirnov test (ZAR 1984; 1999). For the purposes of regression, mean chiasma frequencies were $\log$-transformed and the arcsin transformation was applied to coefficients of variation (STEELE and Torrie 1980). Analysis of Variance (ANOVA), non-parametric correlation and linear and non-linear regressions were employed for data analyses. The XY bivalent, which normally shows a distal chiasma (LANZONE et al. 2002), was excluded from both the chiasma analyses and the calculation of the number of chromosome arms (Fundamental Number, FN), which then became in the Autosomal FN (AFN). Both parameters were $\log$-transformed for statistical purposes.

Observations of synaptonemal complexes (SC) were carried out according to the method described by LANZONE et al. (2002). Briefly, meiotic cells were released in TC 199 medium and centrifuged 3 times for $15 \mathrm{~min}$ at $1500 \mathrm{rpm}$. The spreading medium ( $1 \%$ Triton $\mathrm{X}-100, \mathrm{pH}=7.5)$ was added on a plastic-coated slide with two drops of the cell suspension and left for $12 \mathrm{~min}$. The cells were fixed with $4 \%$ paraformaldehyde. Slides were stained with aqueous $\mathrm{AgNO}_{3}(50 \%)$, selected cells transferred to EM grids and examined under a Jeol 1010 electron microscope.

\section{RESULTS}

Meiotic characteristics of tuco-tucos and chiasma responses to variations in diploid number - Populations along the Saladas- Mburucuyá transect were polymorphic for $\mathrm{Rb}$ rearrangements: all karyomorphs but one were heterozygous for one or two $\mathrm{Rb}$ translocations (Fig. 2; Table 1). The three males from Chavarría formed 29 bivalents in 
Table 1 - Localities, geographic coordinates, diploid chromosome numbers (2n) and number of Rb trivalents (III), autosomal fundamental number (AFN), and mean frequencies of total (T), proximal (P), interstitial (I) and distal (D) chiasmata per cell $( \pm \mathrm{SD})$ in males of the Ctenomys perrensi superspecies and in males from the selected control species of Ctenomys and Tympanoctomys. The asterisks indicates those individuals selected for SC study.

\begin{tabular}{|c|c|c|c|c|c|c|c|c|}
\hline \multirow{2}{*}{ Taxon } & \multirow{2}{*}{ Locality } & \multirow{2}{*}{ Coord. } & \multirow{2}{*}{ 2n (III) } & \multirow{2}{*}{$\mathrm{AFN}$} & \multicolumn{4}{|c|}{ Mean cell chiasma frequencies \pm SD } \\
\hline & & & & & $\mathrm{T}$ & $\mathrm{P}$ & I & $\mathrm{D}$ \\
\hline \multirow[t]{15}{*}{ "C. perrensi" } & Curuzú Laurel & $\begin{array}{l}27^{\circ} 56^{\prime} \mathrm{S} \\
57^{\circ} 30^{\prime} \mathrm{W}\end{array}$ & $\begin{array}{l}42 * \\
(0)\end{array}$ & 72 & $28.90 \pm 1.73$ & $1.80 \pm 1.40$ & $6.10 \pm 1.29$ & $21.00 \pm 3.65$ \\
\hline & San Miguel & $\begin{array}{l}28^{\circ} 01^{\prime} \mathrm{S} \\
57^{\circ} 36^{\prime} \mathrm{W}\end{array}$ & $\begin{array}{l}44 \\
(0)\end{array}$ & 72 & $29.80 \pm 1.55$ & $2.10 \pm 0.99$ & $6.50 \pm 1.65$ & $21.20 \pm 2.86$ \\
\hline & $\begin{array}{l}\text { Estancia Rosarito } \\
\text { (Km. 48) }\end{array}$ & $\begin{array}{l}28^{\circ} 06^{\prime} \mathrm{S} \\
58^{\circ} 17^{\prime} \mathrm{W}\end{array}$ & $\begin{array}{l}51 \\
(1)\end{array}$ & 76 & $32.00 \pm 0.71$ & $2.20 \pm 0.84$ & $6.00 \pm 2.35$ & $23.80 \pm 2.59$ \\
\hline & & & $\begin{array}{l}52^{*} \\
(2)\end{array}$ & 76 & $32.00 \pm 1.66$ & $5.11 \pm 1.05$ & $7.44 \pm 1.67$ & $19.44 \pm 2.46$ \\
\hline & $\begin{array}{l}\text { Pago Alegre } \\
(\mathrm{Km} .28)\end{array}$ & $\begin{array}{l}28^{\circ} 05^{\prime}, \mathrm{S} \\
58^{\circ} 22^{\prime} \mathrm{W}\end{array}$ & $\begin{array}{l}56^{*} \\
(2)\end{array}$ & 80 & $34.44 \pm 2.01$ & $4.33 \pm 1.00$ & $6.00 \pm 2.12$ & $24.11 \pm 2.32$ \\
\hline & Pago de los Deseos (Km. 10) & $\begin{array}{l}28^{\circ} 15^{\prime} \mathrm{S} \\
58^{\circ} 31^{\prime} \mathrm{W}\end{array}$ & $\begin{array}{l}56^{*} \\
(2)\end{array}$ & 80 & $35.14 \pm 1.68$ & $3.71 \pm 1.60$ & $7.86 \pm 1.86$ & $23.57 \pm 3.15$ \\
\hline & $\begin{array}{l}\text { Pje. Sto. Domingo } \\
(\mathrm{Km} .7,5)\end{array}$ & $\begin{array}{l}28^{\circ} 15^{\prime} \mathrm{S} \\
58^{\circ} 33^{\prime} \mathrm{W}\end{array}$ & $\begin{array}{l}55 \\
(1)\end{array}$ & 78 & $34.89 \pm 1.54$ & $2.22 \pm 0.83$ & $5.44 \pm 1.42$ & $27.22 \pm 2.49$ \\
\hline & & & $\begin{array}{l}54 \\
(2)\end{array}$ & 78 & $34.40 \pm 1.14$ & $4.40 \pm 1.14$ & $6.80 \pm 1.64$ & $23.20 \pm 1.48$ \\
\hline & Chavarria & $\begin{array}{l}28^{\circ} 56^{\prime} \mathrm{S} \\
58^{\circ} 36^{\prime} \mathrm{W}\end{array}$ & $\begin{array}{l}58 \\
(0)\end{array}$ & 80 & $38.56 \pm 1.33$ & $5.44 \pm 0.73$ & $6.22 \pm 1.09$ & $26.89 \pm 1.90$ \\
\hline & & & $\begin{array}{l}58 \\
(0)\end{array}$ & 80 & $37.89 \pm 1.05$ & $5.89 \pm 1.05$ & $6.11 \pm 1.83$ & $25.67 \pm 2.87$ \\
\hline & & & $\begin{array}{l}58 \\
(0)\end{array}$ & 80 & $38.17 \pm 1.17$ & $5.67 \pm 1.21$ & $6.83 \pm 1.33$ & $25.67 \pm 2.07$ \\
\hline & Saladas & $\begin{array}{l}28^{\circ} 16^{\prime} \mathrm{S} \\
58^{\circ} 39^{\prime} \mathrm{W}\end{array}$ & $\begin{array}{l}54 \\
(0)\end{array}$ & 82 & $35.50 \pm 2.56$ & $2.50 \pm 0.93$ & $6.75 \pm 1.28$ & $26.25 \pm 3.77$ \\
\hline & & & $\begin{array}{l}55 \\
(1)\end{array}$ & 82 & $35.25 \pm 1.91$ & $1.50 \pm 0.76$ & $5.88 \pm 1.64$ & $27.88 \pm 3.04$ \\
\hline & Santa Rosa & $\begin{array}{l}28^{\circ} 11^{\prime}, \mathrm{S} \\
58^{\circ} 07^{\prime} \mathrm{W}\end{array}$ & $\begin{array}{l}66 \\
(0)\end{array}$ & 80 & $37.33 \pm 2.70$ & $8.83 \pm 1.17$ & $10.17 \pm 1.17$ & $18.33 \pm 2.50$ \\
\hline & & & $\begin{array}{l}65^{*} \\
(1)\end{array}$ & 80 & $38.78 \pm 1.20$ & $8.44 \pm 1.13$ & $9.89 \pm 1.05$ & $20.44 \pm 1.67$ \\
\hline C. roigi & Costa Mansión & $\begin{array}{l}28^{\circ} 02^{\prime} \mathrm{S} \\
58^{\circ} 49^{\prime} \mathrm{W}\end{array}$ & $\begin{array}{l}48 \\
(0)\end{array}$ & 76 & $31.00 \pm 0.00$ & $2.50 \pm 2.12$ & $4.00 \pm 0.00$ & $24.50 \pm 2.12$ \\
\hline C. dorbignyi & Mbarigüí & $\begin{array}{l}27^{\circ} 33^{\prime} \mathrm{S} \\
57^{\circ} 31^{\prime} \mathrm{W}\end{array}$ & $\begin{array}{l}70 \\
(0)\end{array}$ & 80 & $40.13 \pm 2.75$ & $6.20 \pm 1.92$ & $6.40 \pm 2.19$ & $27.40 \pm 3.97$ \\
\hline C. opimus & Piedra del Molino & $\begin{array}{l}25^{\circ} 11^{\prime} \mathrm{S} \\
65^{\circ} 51^{\prime} \mathrm{W}\end{array}$ & $\begin{array}{l}26 \\
(0)\end{array}$ & 48 & $21.00 \pm 1.58$ & $3.20 \pm 1.30$ & $4.00 \pm 1.22$ & $13.80 \pm 1.79$ \\
\hline T. barrerae & El Nihuil & $\begin{array}{l}35^{\circ} 02^{\prime} \mathrm{S} \\
68^{\circ} 40^{\prime} \mathrm{W}\end{array}$ & $\begin{array}{l}102 \\
(0)\end{array}$ & 198 & $55.50 \pm 2.56$ & $8.50 \pm 3.66$ & $7.88 \pm 2.80$ & $40.38 \pm 4.53$ \\
\hline
\end{tabular}

meiosis. One of the analysed males from Santa Rosa showed 33 bivalents $(2 n=66)$, while the other one had $2 \mathrm{n}=65$ and showed a Rb trivalent. On the other hand, specimens from Curuzú Laurel and San Miguel had either 22 or 21 bivalents (Table 1; Fig. 2). Karyotypic and chiasmatic data of individuals from control species are shown in Table 1; any of them was heterozygous for $\mathrm{Rb}$ translocations.

An ANOVA was conducted to determine whether total chiasma frequency varied among " $C$. perrensi" karyotypes. Homogeneity of variances was determined by the Bartlett's test (SoKAL and RohlF 1998) ( $\left.\chi^{2}=16.82 ; \mathrm{df}=14 ; 0.20<\mathrm{P}<0.30\right)$. Differences among karyotypes were statistically highly significant $(\mathrm{F}=27.97 ; \mathrm{df}=1,14, \mathrm{P}<0.01)$.

Since the diploid chromosome number $(2 \mathrm{n})$ and the AFN departed from normality despite log-transformation, non-parametric Spearman correlations were calculated between $2 \mathrm{n}, \mathrm{AFN}$, the frequencies of $\mathrm{T}, \mathrm{P}, \mathrm{I}$ and $\mathrm{D}$ chiasmata, and their respective coefficients of variation $(\mathrm{CV})(\mathrm{Ta}$ ble 2). It can be observed that in "C. perrensi" both total $(\mathrm{T})$ and proximal $(\mathrm{P})$ chiasmata increase significantly with $2 \mathrm{n}$. T chiasmata also increase with AFN; however, a partial correlation analysis using $2 \mathrm{n}$ as a control variable, eliminated the statistical significance of the T/AFN correlation $(\mathrm{r}=0.496 ; \mathrm{df}=12 ; P=0.071)$. It is noteworthy that the coefficient of variation of $P$ chiasmata was negatively correlated with $2 \mathrm{n}$ (Table 2; Fig. 3b) and also with the frequency of $\mathrm{P}$ chiasmata (Fig. 3c). Similar tendencies and correlations were obtained when the control species were included (Table 2), with the exception of a significant negative correlation between interstitial (I) and $2 \mathrm{n}$. 


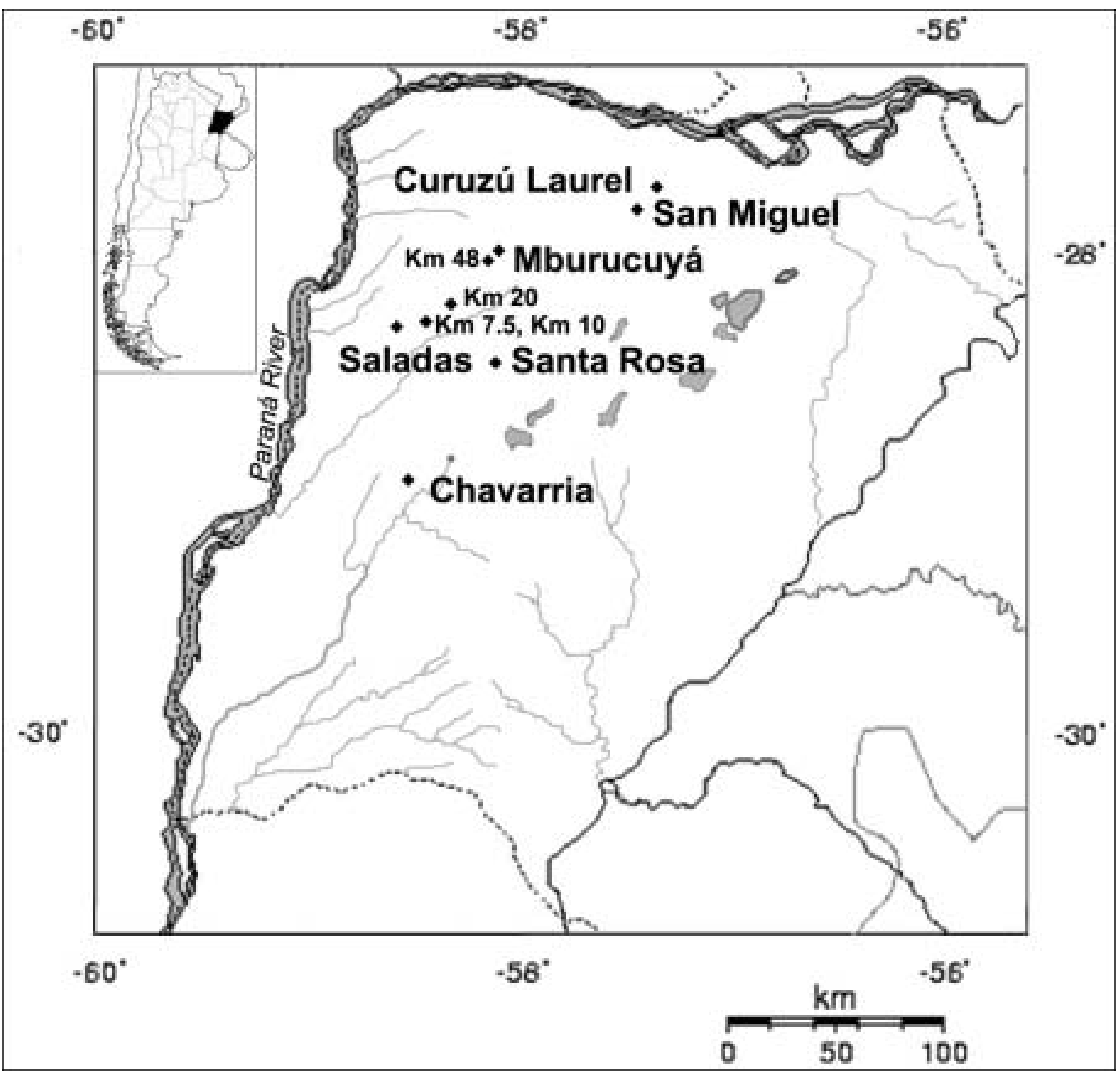

Fig. 1 - Sampling localities of the Ctenomys perrensi superspecies.

Also, the correlation between $\mathrm{T}$ and AFN lost its statistical significance when $2 \mathrm{n}$ was the control variable $(\mathrm{r}=0.31 ; \mathrm{df}=16 ; P=0.356)$ although that between $\mathrm{D}$ and AFN was maintained ( $\mathrm{r}-0510$; $\mathrm{df}=16 ; P=0.031$ ).

Despite many of the relationships were not linear, we have calculated linear regressions between $\mathrm{T}, \mathrm{P}, \mathrm{I}$ and $\mathrm{D}$ chiasmata to best visualise the variations of chiasma frequencies in relation to $2 \mathrm{n}$. Nevertheless, we have included the best non-linear models obtained to understand best the dynamics of the chiasmata/chromosome morpholgy relationship (Table 3). In "C. perrensi" there were positive correlations between $\mathrm{T}, \mathrm{P}$ and I chiasmata frequencies and the chromosome number
(Table 3; Fig. 3a). However, the frequency of D chiasmata was not related to the variation in chromosome number (Fig. 3a; Table 3) although a complex non-linear relationship between $\mathrm{D}$ and 2n may exist (Table 3 ). When the control species were included in the analyses the same tendencies were found (Table 3; Fig. 3b).

All $\mathrm{Rb}$ trivalents exhibited similar chiasma frequencies and distributions, despite having originated from independent $\mathrm{Rb}$ translocations (contingency $\chi^{2}=12.41 ;$ d.f. $=20 ; 0.900<\mathrm{P}<0.975$ ). However, all trivalents had higher frequencies of $\mathrm{P}$ and I chiasmata than the rest of the chromosome complement (contingency $\chi^{2}=121.41 ; \mathrm{gl}=2$; $\mathrm{P}<0.001$ ) (Table 4). 


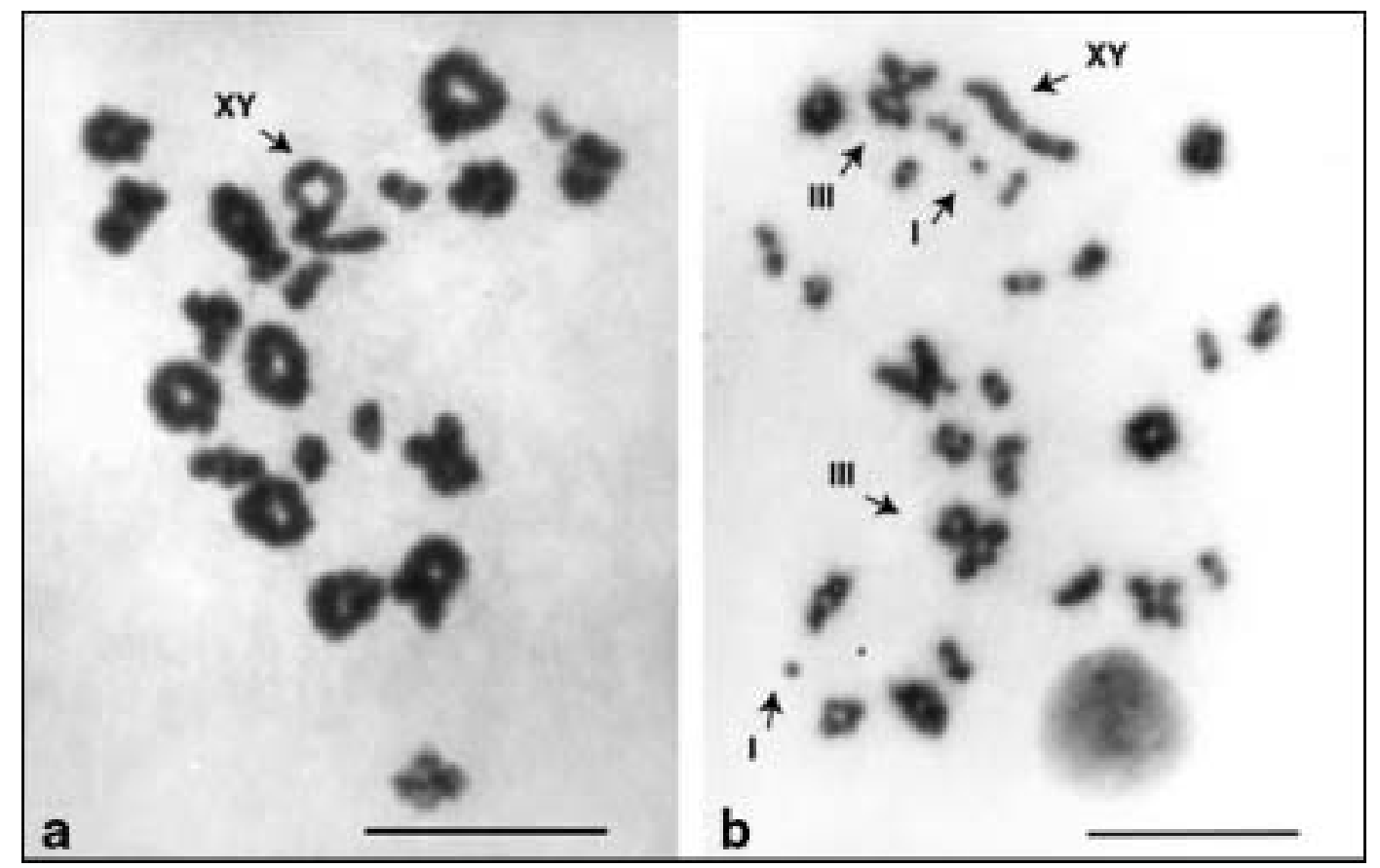

Fig. 2 - Diakinesis cells from individuals of "Ctenomys perrensi" with different chromosome constitutions. (a) $2 \mathrm{n}=$ 42 , structural homozygote. (b) $2 \mathrm{n}=56$, double Robertsonian heterozygote. Note the presence of two autosomal univalents (arrows). III = Robertsonian trivalent, $\mathrm{I}=$ univalent, $\mathrm{XY}=$ sex pair. $\mathrm{Bar}=10 \mu \mathrm{m}$.

Table 2 - Spearman correlation coefficients between log-transformed total (T), proximal (P), interstitial (I) and distal (D) mean chiasma frequencies, their respective arcsin-transformed coeffcients of variation (CV), and diploid chromosome numbers (2n) and AFNs (log-transformed) of all karyotypes in the C. perrensi superspecies (upper rows) and when the control species were added to the analyses (lower rows). Probability (in italics) is indicated for all significant correlations. Two marginally significant correlations are shown in bold type. ns = non-significant.

\begin{tabular}{|c|c|c|c|c|c|c|c|c|c|}
\hline & & \multicolumn{8}{|c|}{ Spearman's rho } \\
\hline \multicolumn{2}{|c|}{ Taxon } & \multicolumn{4}{|c|}{$\arcsin$ Chiasma Frequencies } & \multicolumn{4}{|c|}{ Coefficients of Variation } \\
\hline & & $\mathrm{T}$ & $\mathrm{P}$ & I & $\mathrm{D}$ & CVT & CVP & CVI & CVD \\
\hline "C. perrensi" & $2 \mathrm{n}$ & $\begin{array}{l}0.892 \\
0.000\end{array}$ & $\begin{array}{l}0.801 \\
0.000\end{array}$ & ns & ns & ns & $\begin{array}{c}-0.766 \\
0.001\end{array}$ & ns & ns \\
\hline "C. perrensi" & AFN & $\begin{array}{l}0.758 \\
0.001\end{array}$ & ns & ns & $\begin{array}{l}0.492 \\
0.063\end{array}$ & ns & ns & ns & ns \\
\hline All species & $2 \mathrm{n}$ & $\begin{array}{l}0.947 \\
0.000\end{array}$ & $\begin{array}{l}0.808 \\
0.000\end{array}$ & $\begin{array}{l}0.566 \\
0.012\end{array}$ & $\begin{array}{l}0.438 \\
0.061\end{array}$ & ns & $\begin{array}{c}-0.570 \\
0.011\end{array}$ & ns & ns \\
\hline All species & AFN & $\begin{array}{l}0.841 \\
0.000\end{array}$ & ns & ns & $\begin{array}{l}0.639 \\
0.003\end{array}$ & ns & ns & ns & ns \\
\hline
\end{tabular}

Incidence of univalents - Autosomal univalents, originated from chiasma failure in bivalents and trivalents, were recorded at diakinesis (Table 4; Fig. 2b). Individuals heterozygous for Rb translocations tended to show a higher frequency of univalents per cell $(18.03 \%)$ than homozygotes $(6.90 \%)$. Desynapsis of the XY pair was observed at relatively low frequencies $(0-20 \%)$, although the Santa Rosa males had the highest frequency of XY dissociation, 30\% (Table 5).
Analysis of Synaptonemal Complexes (SCs) - Six complete pachytene nuclei from the Curuzú Laurel male $(2 n=42)$ (Table 1$)$, were selected and measured on photographic enlargements. The total average autosomal haploid SC length was $258.06 \pm 10.38 \mu \mathrm{m}$. In addition, 53 trivalents from thirty nuclei belonging to four individuals were studied (Table 1).

At pachytene, trivalents presented different patterns of synapsis although neither complex 

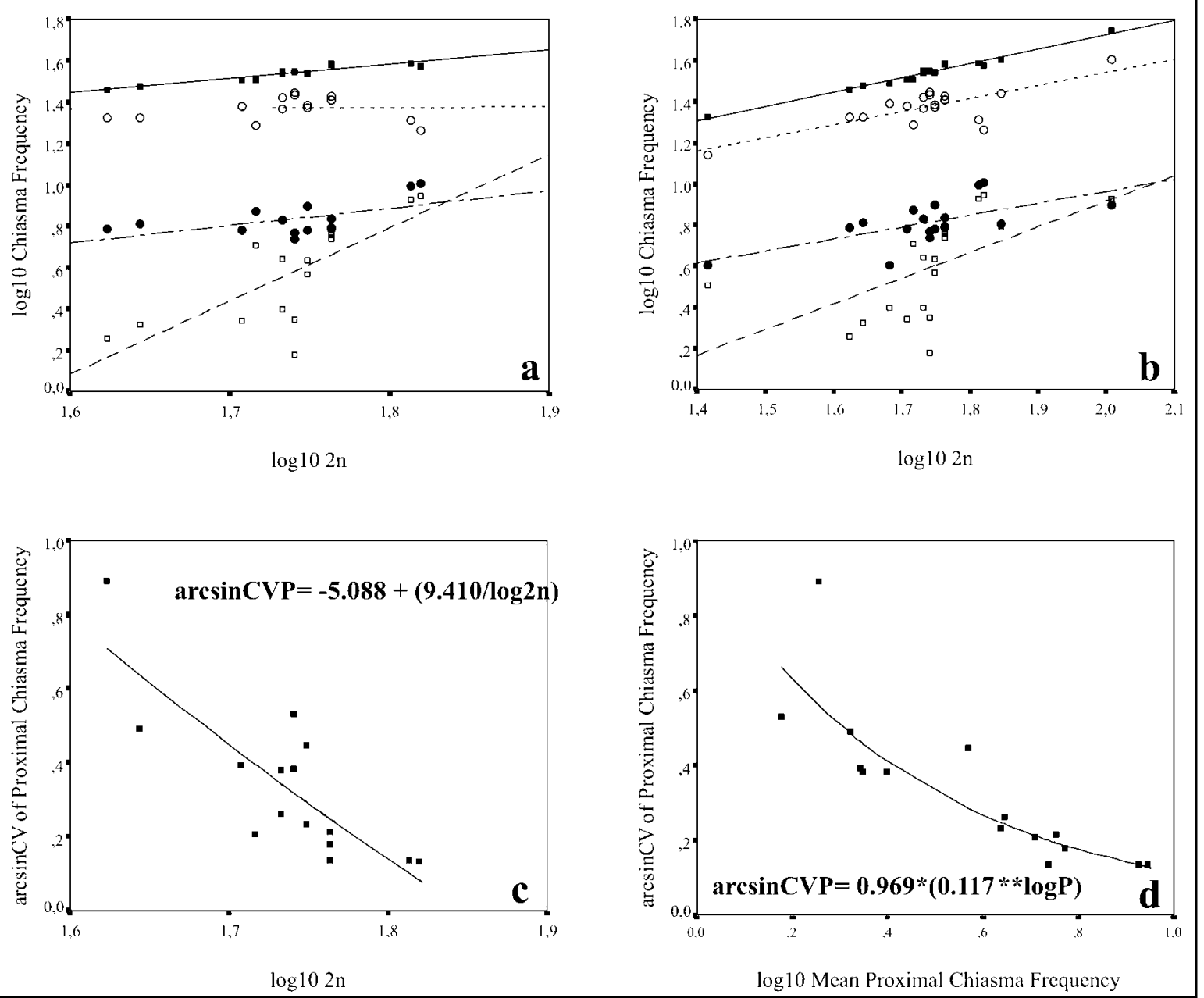

Fig. 3 - Linear regressions between log-transformed total $(\mathbf{\square})$, proximal $(\square)$, interstitial $(\bigcirc)$ and distal $(\bigcirc)$ chiasma frequencies and $\log -2 \mathrm{n}$ of, a. Males of "C. perrensi" with different karyotypes $(2 \mathrm{n}=42-66)$ and $\mathbf{b}$. Males of all species analysed $(2 \mathrm{n}=42-102)$ (see Table 3 for regression equations). c. Non-linear regression (inverse model) between the coefficient of variation $(\arcsin \mathrm{CV}$ ) of proximal chiasma frequency and $2 \mathrm{n}$ in males of " $C$. perrensi" with different karyotypes. $\mathbf{d}$. Non-linear regression (compound model) between the coefficient of variation (arcsinCV) of proximal chiasma frequency and log-transformed proximal chiasma frequencies of males of " $C$. perrensi" with different karyotypes.

Table 3 - Linear and non-linear regression equations between log-transformed total (T), proximal (P), interstitial (I) and distal (D) chiasma frequencies and the $\log 2 \mathrm{n}$ in the C. perrensi superspecies (upper row of each pair of equations) and when the control species were added to the analyses (lower row of each pair). $\mathrm{F}=\mathrm{F}$ statistic; $P=$ statistical significance.

\begin{tabular}{|c|c|c|c|c|c|c|}
\hline $\begin{array}{l}\text { Relation- } \\
\text { ship }\end{array}$ & Linear regression & $\mathrm{F}$ & $P$ & Non-linear regression & $\mathrm{F}$ & $P$ \\
\hline T vs. $2 n$ & $\begin{array}{l}\mathrm{T}=0.324+0.701 * 2 \mathrm{n} \\
\mathrm{T}=0.320+0.703 * 2 \mathrm{n}\end{array}$ & $\begin{array}{r}73.26 \\
507.23\end{array}$ & $\begin{array}{l}0.000 \\
0.000\end{array}$ & $\begin{array}{l}\mathrm{T}=\mathrm{e}^{* * *}[1.216+(-1.361 / 2 \mathrm{n})] \\
\mathrm{T}=0.689+\left(1.588^{* * 2 \mathrm{n})}\right.\end{array}$ & $\begin{array}{r}79.05 \\
551.92\end{array}$ & $\begin{array}{l}0.000 \\
0.000\end{array}$ \\
\hline P vs. 2n & $\begin{array}{l}P=-5.581+3.541 * 2 n \\
P=-1.575+1.245 * 2 n\end{array}$ & $\begin{array}{r}16.76 \\
8.72\end{array}$ & $\begin{array}{l}0.001 \\
0.009\end{array}$ & $\begin{array}{l}\mathrm{P}=6.499+(-10.293 / 2 \mathrm{n}) \\
\mathrm{P}=5.842-7.481 * 2 \mathrm{n}+2.555 * 2 \mathrm{n} * 2\end{array}$ & $\begin{array}{l}15.71 \\
5.80\end{array}$ & $\begin{array}{l}0.002 \\
0.013\end{array}$ \\
\hline I vs. $2 n$ & $\begin{array}{l}\mathrm{I}=-0.636+0.846 * 2 \mathrm{n} \\
\mathrm{I}=-0.198+0.581 * 2 \mathrm{n}\end{array}$ & $\begin{array}{r}5.80 \\
11.72\end{array}$ & $\begin{array}{l}0.032 \\
0.003\end{array}$ & $\begin{array}{l}\mathrm{I}=11.884-11.721 * 2 \mathrm{n} * * 2+4.633 * 2 \mathrm{n} * * 3 \\
\mathrm{I}=\mathrm{e}^{* *}[1.048+(-2.189 / 2 \mathrm{n})]\end{array}$ & $\begin{array}{l}10.22 \\
13.76\end{array}$ & $\begin{array}{l}0.003 \\
0.002\end{array}$ \\
\hline $\mathrm{D}$ vs. $2 \mathrm{n}$ & $\begin{array}{l}\mathrm{D}=1.289+0.047 * 2 \mathrm{n} \\
\mathrm{D}=0.272+0.635 * 2 \mathrm{n}\end{array}$ & $\begin{array}{l}0.020 \\
24.24\end{array}$ & $\begin{array}{l}0.879 \\
0.000\end{array}$ & $\begin{array}{l}\mathrm{D}=-19.286-18.004 * 2 \mathrm{n}-2.021 * 2 \mathrm{n} * * 3 \\
\mathrm{D}=\mathrm{e}^{* *}[1.085+(-1.330 / 2 \mathrm{n})]\end{array}$ & $\begin{array}{r}5.10 \\
25.10\end{array}$ & $\begin{array}{l}0.025 \\
0.000\end{array}$ \\
\hline
\end{tabular}


Table 4 - Relative frequencies of proximal (P), interstitial (I) and distal (D) chiasmata in bivalents (II) and trivalents (III) of "Ctenomys perrensi" heterozygous for Rb translocations.

\begin{tabular}{|c|c|c|c|c|c|c|}
\hline \multirow{2}{*}{ Individual } & \multicolumn{3}{|c|}{ II } & \multicolumn{3}{|c|}{ III } \\
\hline & $\mathrm{P}$ & $\mathrm{I}$ & $\mathrm{D}$ & $\mathrm{P}$ & $\mathrm{I}$ & $\mathrm{D}$ \\
\hline $2 n=51$ & 0.05 & 0.18 & 0.77 & 0.25 & 0.33 & 0.42 \\
\hline $2 \mathrm{n}=52$ & 0.14 & 0.22 & 0.64 & 0.32 & 0.29 & 0.39 \\
\hline $2 n=54$ & 0.09 & 0.21 & 0.70 & 0.39 & 0.09 & 0.52 \\
\hline $2 \mathrm{n}=55(\mathrm{Km} \mathrm{7.5})$ & 0.05 & 0.15 & 0.80 & 0.29 & 019 & 0.52 \\
\hline $2 \mathrm{n}=55$ (Saladas) & 0.03 & 0.17 & 0.80 & 0.19 & 0.19 & 0.62 \\
\hline $2 \mathrm{n}=56(\mathrm{Km} \mathrm{10})$ & 0.07 & 0.22 & 0.71 & 0.29 & 0.27 & 0.44 \\
\hline $2 n=56$ (Pago Alegre) & 0.10 & 0.15 & 0.75 & 0.36 & 0.33 & 0.31 \\
\hline
\end{tabular}

Table 5 - Frequency of univalents at diakinesis in different karyomorphs of the Ctenomys perrensi superspecies. Univalents produced by bivalents (II), Rb trivalents (III) or the sex pair (XY) are discriminated.

\begin{tabular}{|c|c|c|c|c|c|c|}
\hline \multirow{2}{*}{$\begin{array}{c}\text { Number of } \\
\text { heterozygous } \\
\text { Rb translocations }\end{array}$} & \multirow{2}{*}{$2 n$} & \multicolumn{3}{|c|}{ Frequency of autosomal univalents } & \multirow{2}{*}{$\begin{array}{c}\text { XY } \\
\text { univalents }\end{array}$} & \multirow{2}{*}{$\begin{array}{l}\text { Number } \\
\text { of cells }\end{array}$} \\
\hline & & II & III & Total & & \\
\hline 1 & 55 & 0.2 & 0.2 & 0.4 & 0.1 & 9 \\
\hline 1 & 51 & 0 & 0 & 0 & 0 & 5 \\
\hline 1 & 55 & 0 & 0.1 & 0.1 & 0 & 8 \\
\hline 2 & 56 & 0 & 0.1 & 0.1 & 0 & 7 \\
\hline 0 & 54 & 0.1 & 0 & 0.1 & 0.1 & 8 \\
\hline 2 & 52 & 0 & 0.2 & 0.2 & 0.1 & 9 \\
\hline 2 & 54 & 0.2 & 0 & 0.2 & 0.2 & 5 \\
\hline 2 & 56 & 0.2 & 0 & 0.2 & 0.1 & 9 \\
\hline 0 & 58 & 0.1 & 0 & 0.1 & 0.1 & 9 \\
\hline 0 & 58 & 0 & 0 & 0 & 0.1 & 9 \\
\hline 0 & 58 & 0.2 & 0 & 0.2 & 0.2 & 6 \\
\hline 0 & 44 & 0 & 0 & 0 & 0 & 10 \\
\hline 0 & 42 & 0 & 0 & 0 & 0.1 & 10 \\
\hline 0 & 66 & 0.2 & 0 & 0.2 & 0.3 & 6 \\
\hline 1 & 65 & 0 & 0 & 0 & 0.3 & 9 \\
\hline
\end{tabular}

multivalent SCs nor associations with the XY pair were observed (Fig. 4). Thus, 24\% of trivalents (13/53) showed complete synapsis (Fig. 4a). In $49 \%$ of configurations side arms involving both acrocentric chromosomes (25/53) or fold-back loops in one of the acrocentrics $(1 / 53)$ were observed, suggesting non-homologous synapsis at pericentromeric regions (Fig. $4 \mathrm{~b}$ ). In $27 \%$ of trivalents (14/53) some asynapsis at the centromeric ends of acrocentric chromosomes was recorded (Figs.4c, d and e). Cis configurations of the acrocentric centromeres with respect to the metacentric centromere were more frequent than those in trans, (Figs. 4c, d and e).

\section{DISCUSSION}

Examples of polymorphic $\mathrm{Rb}$ fusions are found in mammals as Mus musculus domesticus, Holochilus brasiliensis, Sorex spp. and Suncus murinus (NACHMAN 1992a; b; ZIMA et al. 1994;
Rogatcheva et al. 1997; 1998; Bidau et al. 2001), and insects (BIDAu 1990; BIDAu and Martí 2002). Apart from an instantaneous decrease of interchromosomal recombination by reducing independently assorting elements, fusions reduce intrachromosomal recombination and modify chiasma patterns correlated with the number of $\mathrm{Rb}$ configurations present (BIDAU 1990; NACHMAN 1992b; Bidau et al. 2001; BidAu and Martí 2002; Castiglia and Capanna 2002; Dumas and BRITTON-DAVIDIAN 2002).

In tuco-tucos of the $C$. perrensi superspecies a comparable repatterning of chiasmata occurs. Karyomorphs with different $\mathrm{Rb}$ translocations show a reduction of chiasma frequency and changes in chiasma distribution, suggesting that $\mathrm{Rb}$ translocations may be involved in the control of recombination thus, determining the potential amount of variability released by different karyomorphs in different populations (BIDAU et al. 2001) (however, see below). The mechanics involved in chiasma repatterning are poorly known (Martí and Bidau 2001). In Ctenomys, the reduc- 


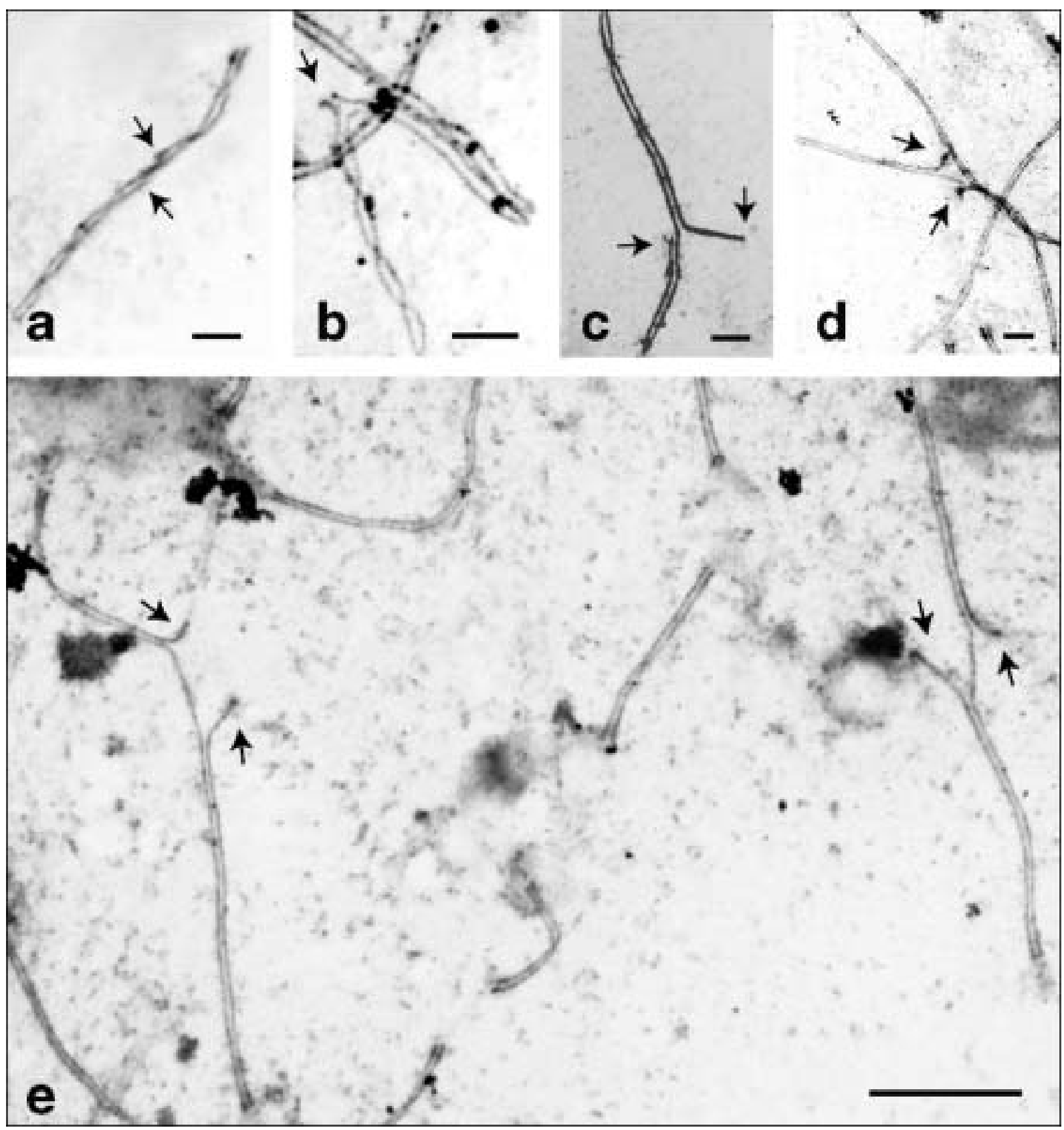

Fig. 4 - Selected pericentromeric regions of the acrocentric chromosomes (arrows) in pachytene Robertsonian trivalents of "C. perrensi" illustrating different synaptic features. a. Full linear synapsis between the three chromosomes. b. Side arm SC formed by heterosynapsis between the pericentromeric regions of both acrocentric chromosomes. c. Asynapsis leading to one free acrocentric end. Acrocentric centromeres in trans configuration. d. Small asynapsed region comprising both centromeric ends of acrocentric chromosomes with terminal thickenings. e. Asynapsis leading to two acrocentric ends in trivalents of a double $\mathrm{Rb}$ heterozygote. Note the different configurations of the centromeres, in trans (right) and in cis (left). Bar $=1 \mu \mathrm{m}$.

tion of total chiasma frequency is produced mainly by the elimination of non-distal chiasmata as has been reported in other species. Nevertheless, several points are worth of discussion.

i) Although there is a general decrease of total chiasma frequency when the chromosome number decrease, it is clear from the comparison within the " $C$. perrensi" group that not all chromosomal variation is due to $\mathrm{Rb}$ translocations since AFN varies between 72 and 82. Furthermore, this is more obvious when the control species are incorporated to the analyses. In this case, 
AFN (48 to 198 autosomal chromosome arms) varies much more than $2 \mathrm{n}$ (26 to 102 chromosomes). In both instances, the relationship between AFN and $2 \mathrm{n}$ is a complex non-linear (cubic) one indicating that a number of other chromosomal rearrangements, that could also affect chiasmata (albeit in different ways), have certainly played an important role in chromosomal evolution of the group. This fact could also explain the non-linearity of some of the responses of chiasma frequencies to change in diploid number, while in cases where $\mathrm{Rb}$ translocations are the only source of $2 \mathrm{n}$ variation (without $\mathrm{AFN}$ variation) responses are always basically linear (BIDAU 1990; 1993; BIDAU and Martí 1995; Bidau et al. 2001; CAStiglia and CAPANNA 2002; Dumas and BRITTONDAvidian 2002).

ii) It has recently been suggested that in mammals, reciprocal recombination (and thus frequency of chiasmata) is proportional to the number of chromosome arms in the karyotype (Pardo Manuel de Villena and Sapienza 2001). Within our sample, we found such a correspondence between chiasmata and AFN but, its significance dissapeared when $2 \mathrm{n}$ was included as a control variable, which was not tested by these authors in their sample of distantly related species. This result suggests that the number of chromosome arms may predict chiasma frequency when $\mathrm{Rb}$ translocations are the main mechanism of chromosome change in morphology, but not when other rearrangements are involved. This is not to say that the number of chromosome arms does not affect chiasma frequency, but the total number of chromosomes is a more realiable predictor of the amount of recombination within a species.

iii) Unlike other studies, we did not find statistically significant relationships between chiasma frequencies and their variability. Usually, when only $\mathrm{Rb}$ variation is involved, higher chiasma frequencies are positively associated with higher variability of T, P or I chiasmata (BIDAU 1990; BIDAU and MARTí 2002). In the case reported here, the only significant relationships were those between CVP and 2n, and CVP and P chiasma frequency but both were, surprisingly, negative. Proximal chiasmata are the first to be suppresssed when $\mathrm{Rb}$ fusions occur because of the problems they impose on segregation of trivalents (BIDAU 1990; BIDAU and MARTí 1995), thus a reduction of $\mathrm{P}$ chiasmata is accompanied by a decrease in their variability. The situation here observed is difficult to explain but again it may be due to the fact that multiple (and not only $\mathrm{Rb}$ ) rearrangements have operated in this group. Since the number of metacentrics increases from the highest to the lowest $2 \mathrm{n}$ values in our samples, and metacentrics usually have less $\mathrm{P}$ chiasmata than expected, this could imply an opposite trend to the decrease in the number of $\mathrm{P}$ chiasmata with $2 \mathrm{n}$, determining an increase in their variability. In other species (i. e. D. pratensis, MARTí and BIDAU 2001) chiasma formation is directly related to pairing and synaptic patterns. Thus, chiasmata would have a P-D distribution in acrocentric bivalents and a D-D distribution in metacentric ones if synapsis starts at the ends of chromosomes and proceeds towards the centromeres (BIDAU 1990; 1993; BIDAU and Martí 1995; Martí and BidAu 1995; 2001). In male meiosis of tuco-tucos, synapsis is normally initiated at chromosome ends, thus chiasma repatterning may obey the same principles as in $D$. pratensis (BIDAU 1990; 1993; 1996; MARTí and BIDAU 2001): chiasmata tend to be more probably formed in chromosomal regions that pair first and remain synapsed longer. The former would explain why the frequency of I chiasmata decreases less than half than that of $\mathrm{P}$ chiasmata when chromosome number decreases as a consequence of $\mathrm{Rb}$ translocations and, why $\mathrm{P}$ chiasmata would be the less likely to be produced in $\mathrm{Rb}$ configurations.

This model of chiasma repatterning explains the chiasmatic behaviour of $\mathrm{Rb}$ metacentric bivalents and trivalents if the underlying mechanism of chiasma formation is identical for both types of $\mathrm{Rb}$ configurations (BIDAu 1993; BIDAu and MARTí 1995). However, in the case of Ctenomys, Rb trivalents showed higher than expected frequencies of $\mathrm{P}$ and I chiasmata, while $\mathrm{Rb}$ bivalents behaved according to the model. Comparable results were found in $\mathrm{Rb}$ trivalents of Mus musculus domesticus (Bidau et al. 2001; CAstiglia and CAPANNA 2002) and perhaps, in Holochilus brasiliensis (NACHMAN 1992b). Thus, what is the plausible mechanism behind the differences in chiasma formation between $\mathrm{Rb}$ heterozygotes and homozygotes in Ctenomys? A testable hypothesis is that telomeric or subtelomeric regions might be involved in recombination initiation. If $\mathrm{Rb}$ translocations of Ctenomys lead to the loss of telomeric regions of acrocentrics then, $\mathrm{Rb}$ metacentric bivalents might be devoid of them in pericentromeric regions of chromosomes while $\mathrm{Rb}$ trivalents would have two extra telomeric regions as represented by both acrocentric chromosomes. The latter may explain the excess of $\mathrm{P}$ and I chiasmata in trivalents. Moreover, if both telomeric and subtelomeric regions of the acrocentrics in the trivalent promote 
chiasma formation independently, a cumulative effect on chiasma formation is expected in absence of chiasma interference across the centromere. In Ctenomys almost 50\% of analysed trivalents presented non-homologous synapsis between the pericentromeric regions of both acrocentric chromosomes, and over $24 \%$ between these regions and the metacentric chromosome. This high frequency of synapsis in the pericentromeric regions suggests no mechanical incompatibilities or SC delay formation in the centromeric region of trivalents, as was described in mouse trivalents with crossover suppression (DAvisson and Akeson 1993). Thus, SC formation may be a major factor related to chiasma distribution in tucotucos. The similarities in chiasma patterns observed in non related species with $\mathrm{Rb}$ translocations suggest that the effect of chiasma repatterning may be related to a general mechanism concerning the formation of metacentric chromosomes (Bidau et al. 2001; Dumas and BrittonDavidian 2002). At pachytene, the sex bivalent and most of $\mathrm{Rb}$ trivalents showed full synapsis that would prevent the deleterious effects produced by the maintenance of unsynapsed regions at the end of pachytene (LANZONE et al. 2002; Turner et al. 2005). These findings suggest the existence of mechanisms that reduce the harmful effects of heterozygous chromosome configurations. Also, the higher frequency of univalents at diakinesis in $\mathrm{Rb}$ heterozygous individuals suggests the possibility of generating unbalanced gametes. However, the lack of correlation between the presence of univalents and the amount of trivalents in a given individual may indicate some influence of the genetic background and of the particular characteristics of the chromosomes involved, as was reported for other mammals (Searle 1993; Nachman and Searle 1995; RoGATCHEVA et al. 1998). The present study supports the idea that one or two Rb translocations in heterozygosis have weak direct effects on the fertility of the male carriers.

Some authors have proposed that relatively neutral variants of $\mathrm{Rb}$ chromosomes are formed and maintained more frequently in some taxa than in others (SEARLE 1993; NACHMAN and Searle 1995; Colangelo et al. 2005). The maintenance of the chromosome polymorphism displayed by the $C$. perrens $i$ superspecies may be promoted by the synaptic behaviour of sex chromosomes and $\mathrm{Rb}$ trivalents (LANZONE et al. 2002, this study). Also, the presence of proximal and interstitial chiasmata in trivalents may help maintain high levels of recombination in heterozygotes, perhaps balancing the effect of the reduction of interchromosomal recombination (BIDAU et al. 2001). Our data suggest that the $C$. perrensi superspecies may be "resistant" to the effects of $\mathrm{Rb}$ chromosomal rearrangements. However, no individual with more than two heterozygous $\mathrm{Rb}$ configurations has yet been found. We conclude that extreme $\mathrm{Rb}$ variation within the $C$. perrensi superspecies is probably not related to evolutionary divergence within this group, supporting the lack of substantial molecular differentiation between chromosomally distinct populations, and even Linnean species (MASCHERETTI et al. 2000; GiméNEZ et al. 2002). It is plausible that present chromosomal variation has been inherited from highly chromosomally polymorphic ancestors (GIMÉNEZ et al. 2002).

Acknowledgments - We are especially indebted to Pavel Borodin for his critical reading of a former draft of this manuscript. We thank Nelly Horak for her assistance with the English version and Esteban Braggio for his assistance during field work and his constant support and encouragement throughout this study. CL and CJB are affiliated to the CONICET (Argentina) and CJB is very grateful to the Conselho Nacional de Desenvolvimento Científico e Tecnológico (CNPq) of Brazil for a Visiting Researcher's grant that allowed the completion of this paper.

\section{REFERENCES}

Anderson S., Yates T.L. and Cook J.A, 1987 Notes on Bolivian mammals. 4. The genus Ctenomys in the eastern lowlands. Am. Mus. Novit., 2891: $1-20$.

Argüelles C.F., Suárez P., Giménez M.D. and BiDAU C.J., 2001 - Intraspecific chromosome variation between different populations of Ctenomys dorbignyi (Rodentia, Ctenomyidae) from Argentina. Acta Theriologica, 46: 363-373.

Baker R.J., Bickham J.W . and Arnold M.L., 1985 Chromosomal evolution in Rhogeessa (Chiroptera: Vespertilionidae): Possible speciation by centric fissions. Evolution, 39: 233-243.

BidAu C.J. and Martí D.A., 1995 - Male and female meiosis in Robertsonian beterozygotes of Dichroplus pratensis (Acrididae). In: P.E. Brandham and M.D. Bennett (Eds), "Kew Chromosome Conference IV”, pp. 381-396. Royal Botanic Gardens Press, Kew.

BidAu C.J. and MARTí D.A., 2002 - Geographic distribution of Robertsonian fusions in Dichroplus pratensis (Melanoplinae, Acrididae): the centralmarginal bypothesis reanalysed. Cytogenet. Genome Res., 96: 66-74.

BidAu C.J., 1990 - The complex Robertsonian system of Dichroplus pratensis (Melanoplinae, Acrididae). II 
Effects of the fusion polymorphisms on chiasma frequency and distribution. Heredity, 64: 145-159.

BidAu C.J., 1993 - Causes of chiasma repatterning due to centric fusions. Braz. J. Genet. 16: 283-296.

BIDAU C.J., 1996 - Chiasma repatterning in bybrids between chromosomal races of the grasshopper Dichroplus pratensis (Melanoplinae, Acrididae). Cytobios, 85: 91-110.

BidAu C.J., 2006 - Familia Ctenomyidae Lesson, 1828. In: R.J. Barquez, M.M. Díaz, and R.A. Ojeda (Eds.), "Mamíferos de Argentina: Sistemática y Distribución”. SAREM, Tucumán, Argentina (in press)

Bidau C.J., Giménez M.D., Palmer C.L. and Searle J.B., 2001 - The effects of Robertsonian fusion on chiasma frequency and distribution in the bouse mouse (Mus musculus domesticus) from a bybrid zone in northern Scotland. Heredity, 87: 305-313.

Braggio E., Giménez M.D., Contreras J.R., Justo E.R. and BIDAU C.J., 2000 - Karyotypic variation in populations of Ctenomys (Rodentia, Ctenomyidae) from La Pampa province (Argentina). Caryologia, 52: 131-140.

Castiglia R. and Capanna E., 2002 - Chiasma repatterning across a chromosomal bybrid zone between chromosomal races of Mus musculus domesticus. Genetica, 114: 36-40.

Colangelo P., Corti M., Verheyen E., Annessi F., Oguge N., Makundi R.H. and Verheyen W., 2005 - Mitochondrial phylogeny reveals differential modes of chromosomal evolution in the genus Tatera (Rodentia: Gerbillinae) in Africa. Mol. Phylogenet. Evol., 35: 556-568.

Davisson M.T. and Akeson E.C., 1993 - Recombination suppression by beterozygous Robertsonian chromosomes in the mouse. Genetics, 133: 649-667.

Dumas D. and BRITTON-DAvidian J., 2002 - Chromosomal rearrangements and evolution of recombination: comparison of chiasma distribution patterns in standard and Robertsonian populations of the bouse mouse. Genetics, 162: 1355-1366.

EIBERg H., 1974 - New selective giemsa technique for buman chromosomes, Cd staining. Nature, 248: 55.

Evans E.P., Breckon G., and Ford C.E., 1964 - An air-drying method for meiotic preparations from mammalian testes. Cytogenetics, 3: 289-294.

Giménez M.D., Contreras J.R. and Bidau C.J., 1997 - Chromosomal variation in Ctenomys pilarensis, a recently described species from eastern Paraguay (Rodentia, Ctenomyidae). Mammalia, 61: 385-398.

Giménez M.D., Bidau C.J., ArgüElles C.F. and Contreras J.R., 1999 - Chromosomal characterization and relationship between two new species of Ctenomys (Rodentia, Ctenomyidae) from northern Córdoba province, Argentina. Z Säugetierkunde, 64: 91-106.

Giménez M.D., Mirol P.M., Bidau C.J. and Searle J.B., 2002 - Molecular analysis of populations of Ctenomys (Caviomorpha, Rodentia) with high karyotypic variability. Cytogenet. Genome Res., 96: 130136.
Hatfield T., Barton N. and Searle J.B., $1992-A$ model of a bybrid zone between two chromosomal races of the common shrew (Sorex araneus). Evolution, 46: 1129-1145.

Hewitt G.M., 1979 - Orthoptera. Grasshoppers and Crickets. In: B. John (Ed), "Animal Cytogenetics, Vol. 3 Insecta 1”, p. 170. Gebrüder Borntraeger, Berlin-Stuttgart.

JoHN B., 1983 - The role of chromosome change in the evolution of orthopteroid insects. In: A.K. Sharma, and A. Sharma (Eds), "Chromosomes in the Evolution of Eukaryotic Groups”, pp. 110. CRC Press, Boca Raton.

Kiblisky P., Brum-Zorrilla N., Pérez G. and Saez F.A., 1977 - Variabilidad cromosómica entre diversas poblaciones del roedor cavador del género Ctenomys (Rodentia, Octodontoidae). Mendeliana, 2: $85-93$.

KIng M., 1993 - Species Evolution: the role of chromosome change. University Press, Cambridge.

Lanzone C., Bidau C.J., Giménez M.D. and Santos J.L., 2002 - Synaptic behaviour and morphological modifications of the $X$ and $Y$ chromosomes during pachytene in three species of Ctenomys (Rodentia, Caviomorpha, Ctenomyidae). Genome, 45: 11101115.

Martí D.A. and BidAu C.J., 2001 - Synapsis in Robertsonian beterozygotes and bomozygotes of Dichroplus pratensis (Melanoplinae, Acrididae) and its relationship with chiasma patterns. Hereditas, 134: 245 254.

Martí D.A. and BidAu J.C., 1995 - Male and female meiosis in natural population of Dichroplus pratensis (Acrididae) polymorphic for Robertsonian translocation: A study of chiasma frequency and distribution. Hereditas, 123: 227-235.

Mascheretti S., Mirol P., Gimenez M.D., Bidau C.J., Contreras J.R. and Searle J.B., 2000 Phylogenetics of the speciose and chromosomally variable genus Ctenomys (Ctenomyidae, Octodontoidea), based on mitochondrial cytochrome $b$ sequences Biol. J. Linn. Soc., 70: 361-376.

Nachman M.W. and Searle J.B., 1995 - Why is the bouse mouse so variable?. Trends Ecol. Evol., 10: 397-402.

NaCHMAN M.W., 1992a - Geographic patterns of chromosomal variation in South American marsh rats, Holochilus brasiliensis and H. vulpinus. Cytogenet. Cell. Genet., 61: 10-16.

Nachman M.W., 1992b - Meiotic studies of Robertsonian polymorphisms in the South American marsh rat, Holochilus brasiliensis. Cytogenet. Cell. Genet., 61: $17-24$

Ortells M.O., 1995 - Phylogenetic analysis of G-banded karyotypes among the South American subterranean rodents of the genus Ctenomys (Caviomorpha: Octodontidae), with special reference to chromosomal evolution and speciation. Biol. J. Linn. Soc., 54: 43-70.

Ortells M.O., Contreras J.R. and Reig O.A., 1990 - New Ctenomys karyotypes (Rodentia, Octodonti- 
dae) from north-eastern Argentina and from Paraguay confirm the extreme chromosomal multiformity of the genus. Genetica, 82: 189-201.

Pardo Manuel de Villena F. and Sapienza C., 2001 - Recombination is proportional to the number of chromosome arms in mammals. Mamm. Genome, 12: 318-322.

Piálex J., Hauffe H.C. and Searle J.B., 2005 Chromosomal variation in the house mouse: review. Biol. J. Linn. Soc., 84: 535-563.

RIESEBERG L.H., 2001 - Chromosomal rearrangements and speciation. Trends. Ecol. Evol., 16: 351-358.

Rogatcheva M.B., Borodin P.M., Oda S.I. and SEARLE J.B., 1997 - Robertsonian chromosomal variation in the house musk shrew (Suncus murinus, Insectivora: Soricidae) and colonization bistory of the species. Genome, 40: 18-24.

Rogatcheva M.B., Oda S.I., Axenovich T.I., Aulchenko Y.S., Searle J.B. and Borodin P.M., 1998 - Chromosomal segregation and fertility in Robertsonian chromosomal beterozygotes of the bouse musk shrew (Suncus murinus, Insectivora, Soricidae). Heredity, 81: 335-341.

SEARLE J.B., 1993 - Chromosomal bybrid zones in eutherian mammals. In: R. Harrison (Ed), "Hybrid Zones and Evolutionary Process", pp. 309-353. Oxford University Press, New York.
Searle J.B., Navarro Y.N. and Ganem G., 1993 Further studies of a staggered bybrid zone in Mus musculus domesticus (the house mouse). Heredity, 71: 523-531.

Sokal R.R. and RohlF F.J., 1998 - Biometry. The principles and practice of statistics in biological research. In: W.H. Freeman (Ed) $3^{\circ} \mathrm{ed}$, pp. 887. San Francisco.

Steel R.G.D. and Torrie J.H., 1980 - Principles and Procedures of Statistics. $2^{\text {nd }}$ Edit. In. McGeaw-Hill (Ed), p. 633. New York.

Turner J.M.A., Mahadevaiah S.K., Fernández-Capetillo O., Nussenzweig Xu X. Deng Ch-X. and Burgoyne P.S., 2005 - Silencing of unsynapsed meiotic chromosomes in the mouse. Nat. Genet., 37: 41-47.

White M.J.D., 1978 - Modes of Speciation. In: W.H. Freeman (Ed), pp. 455. San Francisco.

ZAR J.H., $1984-$ Biostatistical Analysis. $2^{\text {th }}$ Edit. Prentice Hall, p. 713 Englewoods Cliffs, NJ.

ZAR J.H., 1999 - Biostatistical Analysis. $4^{\text {th }}$ Edit. Prentice Hall, p. 663 + Appendixes. Upper Saddle River, NJ.

Zima J., Searle J.B. and Macholan M., 1994 - The cytogenetics of the Sorex araneus group and related topics. F. Zool., 43: 1-116.

Received August $28^{\text {th }}$ 2006; accepted January $1^{\text {th }} 2007$ 